\title{
A Narrow-Band Ultraviolet B Course Improves Vitamin D Balance and Alters Cutaneous CYP27A1 and CYP27B1 mRNA Expression Levels in Haemodialysis Patients Supplemented with Oral Vitamin D
}

\author{
Meri J. Ala-Houhala a,c Katja Vähävihu ${ }^{d}$ Erna Snellman $^{\mathrm{e}}$ Taina Hasan $^{a}$ \\ Hannu Kautiainen ${ }^{f}$ Piia Karisolag ${ }^{\text {Yvonne Dombrowski }}{ }^{\text {h }}$ Jürgen Schauber ${ }^{\text {h }}$ \\ Heikki Sahab Timo Reunalaa,c \\ ${ }^{a}$ Department of Dermatology, and b Internal Medicine, Tampere University Hospital, ' Medical School, University \\ of Tampere, Tampere, d Department of Dermatology, Kanta-Häme Central Hospital, Hämeenlinna, e Department of

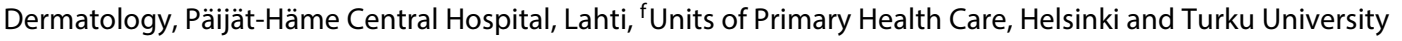 \\ Hospitals, and Department of General Practice, University of Helsinki, g Unit of Systems Toxicology, Finnish Institute \\ of Occupational Health, Helsinki, Finland; 'h Department of Dermatology and Allergy, Ludwig Maximilian University, \\ Munich, Germany
}

\section{Key Words}

Cholecalciferol - Chronic kidney disease - CYP27A1 .

CYP27B1 - Haemodialysis - Ultraviolet B radiation .

Vitamin D

\begin{abstract}
Background/Aims: Chronic kidney disease (CKD) patients on dialysis are prone to vitamin $D$ insufficiency despite oral vitamin $D$ supplementation. Here, we studied whether narrow-band ultraviolet B (NB-UVB) exposures improve vitamin D balance. Methods: 14 haemodialysis patients and 15 healthy subjects receiving oral cholecalciferol $20 \mu \mathrm{g}$ daily got nine NB-UVB exposures on the entire body. Serum 25-hydroxyvitamin $\mathrm{D}(25(\mathrm{OH}) \mathrm{D})$ was measured by radioimmunoassay. Cutaneous mRNA expression levels of CYP27A1 and CYP27B1, two enzymes required for hydroxylation of vitamin $D$ into its active metabolite, were also measured. $\boldsymbol{R e}$ sults: The baseline serum 25(OH)D concentration was $57.6 \pm$
\end{abstract}

$18.2 \mathrm{nmol} / \mathrm{l}$ in the CKD patients and $74.3 \pm 14.8 \mathrm{nmol} / \mathrm{l}$ in the healthy subjects. The NB-UVB course increased serum $25(\mathrm{OH}) \mathrm{D}$ by $14.0 \mathrm{nmol} / \mathrm{l}(95 \% \mathrm{Cl} 8.7-19.5)$ and $17.0 \mathrm{nmol} / \mathrm{l}(\mathrm{Cl}$ 13.7-20.2), respectively. At baseline the CKD patients showed significantly increased CYP27B1 levels compared to the healthy subjects. Conclusions: A short NB-UVB course is an efficient way to improve vitamin $D$ balance in CKD patients on dialysis who are receiving oral vitamin $D$ supplementation. The increased cutaneous CYP27B1 levels in the CKD patients suggest that the loss of renal activity of this enzyme is at least partially compensated for by the skin.

Copyright $\odot 2013$ S. Karger AG, Basel

\section{Introduction}

Vitamin D deficiency is a common complication in pre-dialysis and dialysis patients with chronic kidney disease (CKD) [1-4]. In advanced kidney disease, the

\section{KARGER}

E-Mail karger@karger.com

www.karger.com/nec (c) 2013 S. Karger AG, Basel

$1660-2110 / 13 / 1242-0017 \$ 38.00 / 0$ 
Table 1. Demography, use of oral cholecalciferol before the NB-UVB course and 25(OH)D levels at baseline in 14 CKD patients on haemodialysis and 15 healthy subjects

\begin{tabular}{|c|c|c|c|}
\hline & $\begin{array}{l}\text { CKD patients } \\
(\mathrm{n}=14)\end{array}$ & $\begin{array}{l}\text { Healthy subjects } \\
(\mathrm{n}=15)\end{array}$ & $\mathrm{p}$ value \\
\hline Male/female & $6 / 8$ & $1 / 14$ & 0.035 \\
\hline Body mass index, $\mathrm{kg} / \mathrm{m}^{2}($ mean $\pm \mathrm{SD})$ & $32.1 \pm 8.4$ & $23.6 \pm 3.8$ & 0.001 \\
\hline Fitzpatrick skin type II/III/IV & $5 / 7 / 2$ & $3 / 10 / 2$ & 0.67 \\
\hline Use of cholecalciferol $20 \mu \mathrm{g}$ daily before NB-UVB course, months, median (range) & $2.3(1-16)$ & $2.0(1-24)$ & 0.40 \\
\hline
\end{tabular}

kidney is unable to produce 1,25-dihydroxyvitamin D $\left(1,25(\mathrm{OH})_{2} \mathrm{D}\right)$ from 25 -hydroxyvitamin $\mathrm{D}(25(\mathrm{OH}) \mathrm{D})$ due to loss of renal 1a-hydroxylase (CYP27B1) activity $[5,6]$. An individual's vitamin $D$ status is best evaluated by measuring the level of serum $25(\mathrm{OH}) \mathrm{D}[6,7]$. CKD patients are recommended to have a serum $25(\mathrm{OH}) \mathrm{D}$ concentration $>75.0 \mathrm{nmol} / \mathrm{l}(>30.0 \mathrm{ng} / \mathrm{ml})[8]$. However, this level is difficult to achieve using oral ergocalciferol supplementation for 6 months [9]. A recent meta-analysis on the use of oral vitamin $\mathrm{D}$ compounds in dialysis and non-dialysis CKD patients confirmed significant improvement in serum $25(\mathrm{OH}) \mathrm{D}$ concentration, but no effect on bone or cardiovascular outcomes were found [10].

Artificial ultraviolet B (UVB) skin exposures are another possible method of improving vitamin $\mathrm{D}$ balance because solar UVB radiation is a potent inducer of vitamin D photosynthesis. The synthesis starts from 7-dehydrocholesterol in the skin and is rapidly processed into vitamin $\mathrm{D}$. The next steps of synthesis are programmed in the liver and kidney, but also occur in skin keratinocytes. These cells have CYP27A1 (25-hydroxylase) and CYP27B1 (1 $\alpha$-hydroxylase) enzymes to hydroxylate vitamin $\mathrm{D}$ to $25(\mathrm{OH}) \mathrm{D}$ and further to $1,25(\mathrm{OH})_{2} \mathrm{D}$, which is the active form of vitamin $\mathrm{D}[6,7]$. A narrow-band UVB (NB-UVB) course, which is widely used as treatment for psoriasis, increases serum $25(\mathrm{OH}) \mathrm{D}$ levels in vitamin-Dinsufficient subjects more efficiently than oral cholecalciferol $[11,12]$.

We found previously in CKD patients on haemodialysis who had no oral vitamin $\mathrm{D}$ supplementation that their serum $25(\mathrm{OH}) \mathrm{D}$ levels responded rapidly to a 3 -week NB-UVB course [13]. The $25(\mathrm{OH}) \mathrm{D}$ concentration increased by $43 \%$ and after the NB-UVB course none of the patients were vitamin $\mathrm{D}$ deficient. In the present study, we examined whether a similar short NB-UVB course improves vitamin D balance in dialysis patients receiving standard oral vitamin D supplementation, i.e. cholecalciferol $20 \mu \mathrm{g}$ daily prior to and during the study. In addition, we measured cutaneous messenger RNA (mRNA) expression levels of CYP27A1 and CYP27B1.

\section{Materials and Methods}

\section{CKD Patients on Dialysis and Healthy Subjects}

There were 32 patients in our self-care haemodialysis unit. The inclusion criteria for the study were: age of 18-70 years; no sun tanning within the 2 preceding months; Fitzpatrick skin type IIIV, which indicates that skin does not burn easily in the sun, and daily use of oral cholecalciferol $20 \mu \mathrm{g}$ (800 IU) for at least 1 month. 14 CKD stage 5 patients on haemodialysis ( 6 male, 8 female, mean age 53.6 years; table 1) meeting these criteria were enrolled in the study. The patients had been on dialysis for a mean of 47 (range 9-117) months. During the study, all 14 patients received calcium carbonate, 12 non-calcium-containing phosphate binder, 6 cinacalcet and 7 active vitamin D analogues. The CKD patients had used oral cholecalciferol $20 \mu \mathrm{g}$ daily for a mean of 5.3 (range 1-16) months.

15 hospital employees ( 1 male, 14 female, mean age 46.1 years; table 1) volunteered as controls in the study. These subjects had used oral cholecalciferol $20 \mu \mathrm{g}$ daily for a mean of 3.4 (range 1-24) months. Both groups continued to use cholecalciferol $20 \mu \mathrm{g}$ daily during and after the NB-UVB course.

The ethics committee of Tampere University Hospital approved the study protocol and all subjects gave an informed consent to participate. The authors followed the Declaration of Helsinki.

\section{NB-UVB Exposures}

The study was performed between December 2011 and March 2012. The subjects received nine NB-UVB exposures given three times a week on the entire body with a Waldmann UV 7001 cabin (Schulze \& Böhm, Brühl, Germany). The NB-UVB exposures were given to the patients prior to dialysis. The first NB-UVB dose was $0.19 \mathrm{~J} / \mathrm{cm}^{2}$ (1.11 SED), and this dose was increased according to a fixed protocol gradually up to $0.97 \mathrm{~J} / \mathrm{cm}^{2}$ (5.70 SED). One SED is equivalent to $10 \mathrm{~mJ} / \mathrm{cm}^{2} \mathrm{CIE}$ (Commission Internationale de l'Eclairage) erythema-weighted irradiance. The mean cumulative dose of NB-UVB given to the CKD patients was 4.53 (range 2.97-
18

Nephron Clin Pract 2013;124:17-22 DOI: $10.1159 / 000355010$
Ala-Houhala et al. 


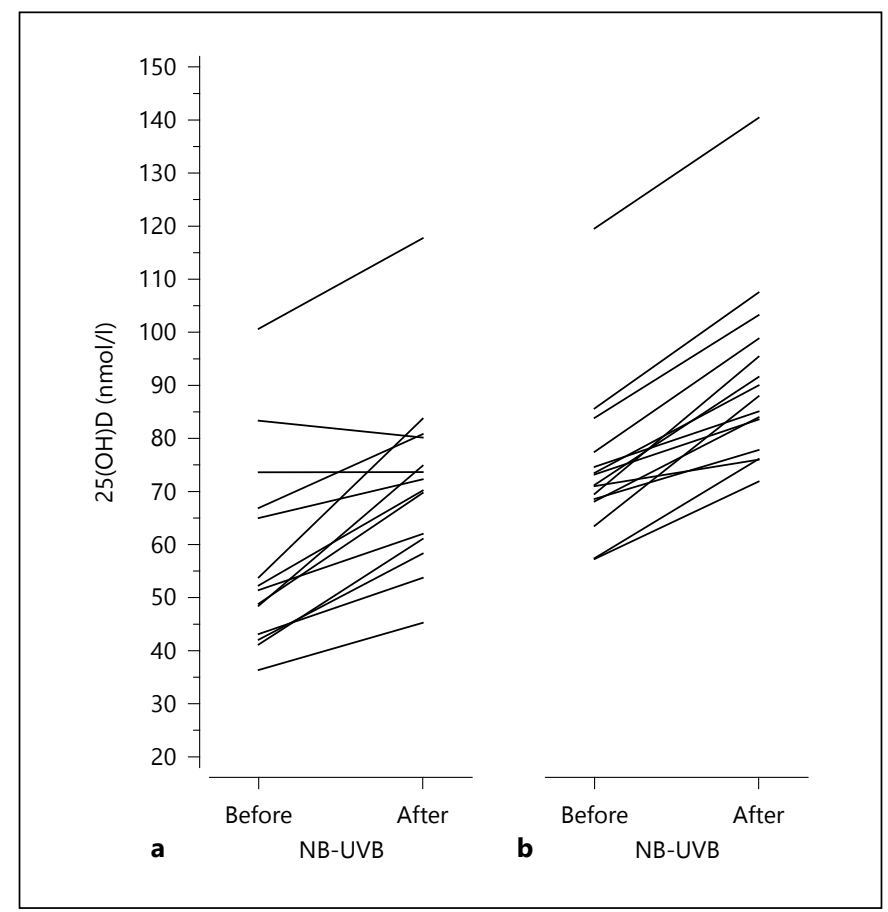

Fig. 1. Serum $25(\mathrm{OH}) \mathrm{D}$ concentrations before and after the NBUVB course in 14 CKD patients on (a) haemodialysis and (b) 15 healthy subjects. The both groups had been receiving oral vitamin $\mathrm{D}$ substitution at a daily dose of $20 \mu \mathrm{g}$. The increase is significant $(\mathrm{p}<0.001)$ in the both groups.

4.75) $\mathrm{J} / \mathrm{cm}^{2}$ which is equivalent to $26.6 \mathrm{SED}$. In the healthy subjects, the mean cumulative dose of NB-UVB was $4.37 \mathrm{~J} / \mathrm{cm}^{2}$ (range 3.21 4.75) which is equivalent to 25.7 SED.

\section{Measurement of Serum 25(OH)D Concentrations}

Blood samples for serum 25(OH)D measurements were taken before the first and the ninth NB-UVB exposures, and follow-up samples 1 and 3 months after the NB-UVB course. The samples were protected from light, centrifuged and then stored at $-70^{\circ} \mathrm{C}$. The $25(\mathrm{OH}) \mathrm{D}$ concentration was analysed in duplicates using a radioimmunoassay (Immunodiagnostic Systems, Boldon, UK) as previously described [13].

\section{Skin Biopsies and Quantitative Real-Time PCR}

Punch biopsies were taken from the buttocks of $10 \mathrm{CKD}$ patients and 13 healthy subjects before the first and the ninth NB-UVB exposures. The biopsies were frozen and stored at $-70^{\circ} \mathrm{C}$. Total RNA was isolated using TRIsure Reagent (Bioline, Luckenwalde, Germany), and $1 \mu \mathrm{g}$ of RNA was reverse transcribed with the High Capacity cDNA Reverse Transcription Kit (Applied Biosystems, Foster City, Calif., USA) to cDNA. The mRNA expression levels of CYP27A1 and CYP27B1 were evaluated using a LightCycler ${ }^{\circledR} 2.0$ system and the corresponding human Universal Probe Library Set (Roche) as previously described [13].

Oral Cholecalciferol, UVB and 25(OH)D

in Dialysis Patients

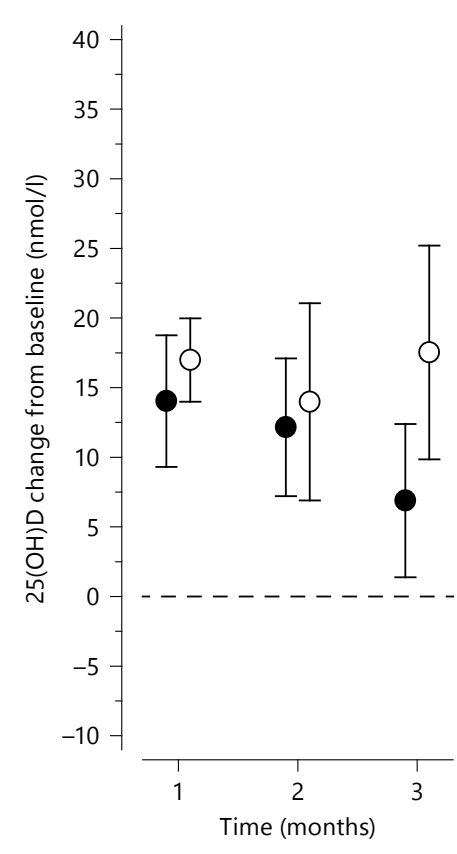

Fig. 2. A NB-UVB course given for 1 month increased serum $25(\mathrm{OH}) \mathrm{D}$ concentration by $24.2 \%$ in $14 \mathrm{CKD}$ patients on haemodialysis (black dots) and by $22.8 \%$ in 15 healthy control subjects (open dots) receiving continuous oral vitamin D substitution. After the NB-UVB exposures, at 2 and 3 months from baseline, 25(OH) $\mathrm{D}$ concentrations were still significantly higher than at baseline in the both groups. Mean values; 95\% CIs are shown by bars.

Table 2. 25(OH)D concentrations and levels of intact parathyroid hormone (PTH), haemoglobin, ionized calcium and phosphorus before and after a NB-UVB course in 14 CKD patients on haemodialysis

\begin{tabular}{lccc}
\hline & $\begin{array}{l}\text { Before } \\
\text { NB-UVB } \\
\text { mean } \pm \text { SD }\end{array}$ & $\begin{array}{l}\text { After } \\
\text { NB-UVB } \\
\text { mean } \pm \text { SD }\end{array}$ & p value \\
& $57.6 \pm 18.2$ & $71.7 \pm 17.2$ & $<0.001$ \\
25(OH)D, nmol/l & $31.8 \pm 29.0$ & $26.7 \pm 25.6$ & 0.11 \\
Intact PTH, pmol/l & $114.2 \pm 11.3$ & $112.3 \pm 9.2$ & 0.39 \\
Haemoglobin, g/l & $1.18 \pm 0.08$ & $1.16 \pm 0.07$ & 0.044 \\
Ionized calcium, mmol/1 & $1.88 \pm 0.44$ & $1.91 \pm 0.32$ & 0.86 \\
Phosphorus, mmol/l & & &
\end{tabular}

\section{Statistics}

The statistical comparison between the groups was performed by $t$ test, permutation test or $\chi^{2}$ test. Repeated measures were analysed using generalizing estimating equations models with the unstructured correlation structure using bootstrap type standard error. The changes within CKD patients were analysed by applying a t test and a permutation test to related samples. 


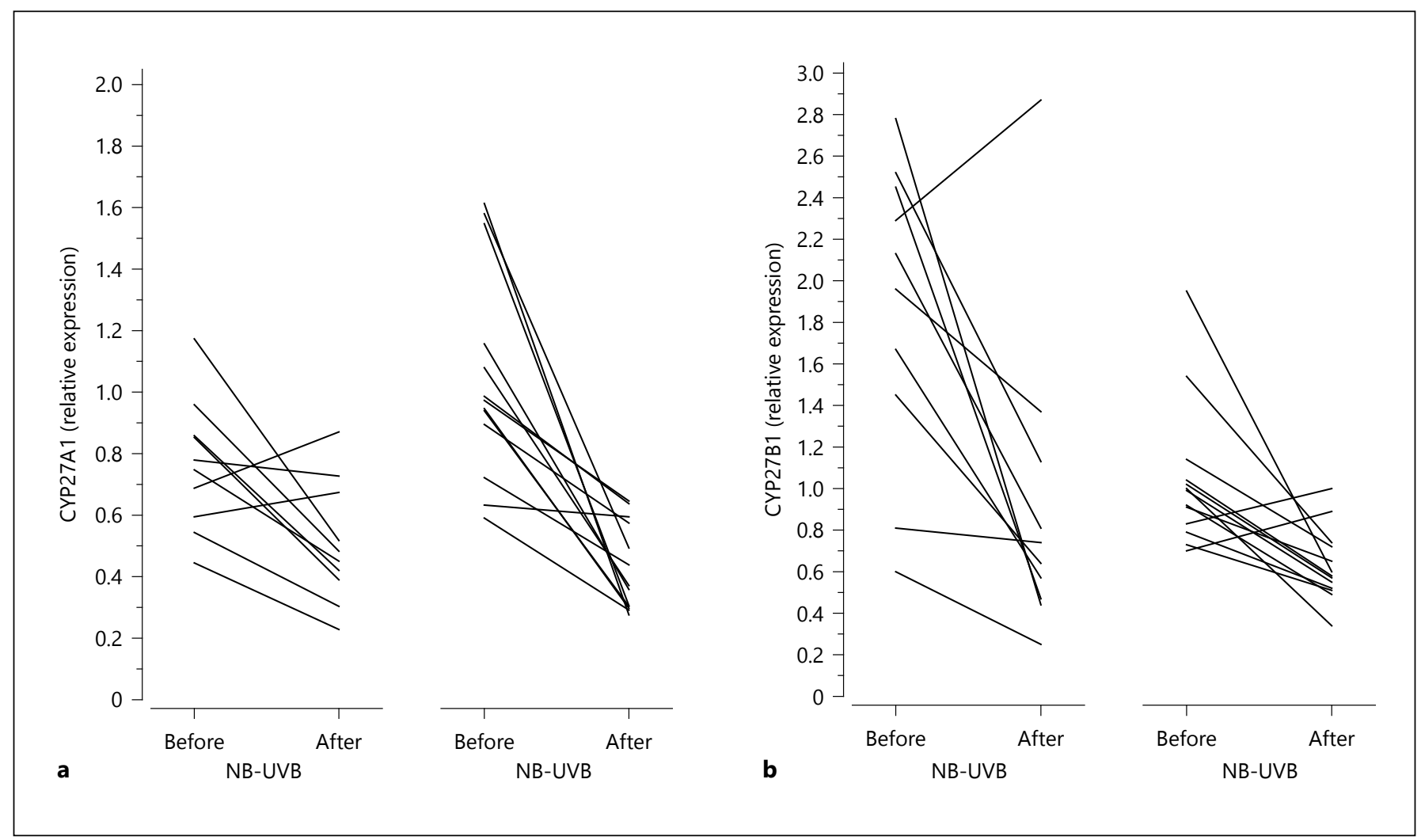

Fig. 3. a CYP27A1 mRNA expression levels in skin biopsies in CKD patients on haemodialysis $(\mathrm{n}=10)(\mathrm{left})$ and healthy subjects $(\mathrm{n}=13)$ (right) before and after the NB-UVB course. Before the NB-UVB course the CYP27A1 levels were significantly $(\mathrm{p}=0.028)$ lower in the CKD patients compared to healthy subjects. The NBUVB course caused a significant decrease in the CYP27A1 levels in the CKD patients $(\mathrm{p}=0.018)$ and healthy subjects $(\mathrm{p}<0.001)$.

\section{Results}

Serum 25(OH)D Concentrations before and after the NB-UVB Course

The baseline serum $25(\mathrm{OH}) \mathrm{D}$ concentration was $57.6 \pm 18.2 \mathrm{nmol} / \mathrm{l}($ mean $\pm \mathrm{SD})$ in the 14 dialysis patients (table 1). The serum $25(\mathrm{OH}) \mathrm{D}$ was $<50.0 \mathrm{nmol} / \mathrm{l}$ in 6 $(43 \%)$ and $<75.0 \mathrm{nmol} / \mathrm{l}$ in another $6(43 \%)$ patients (fig. 1). The NB-UVB course increased serum $25(\mathrm{OH}) \mathrm{D}$ by $14.0 \mathrm{nmol} / \mathrm{l}(95 \% \mathrm{CI} 8.7-19.5, \mathrm{p}<0.001)$, or $24.2 \%$ (fig. 1). Only $1(7 \%)$ patient had serum $25(\mathrm{OH}) \mathrm{D}<50.0$ $\mathrm{nmol} / \mathrm{l}$. NB-UVB treatment had only marginal effects on the other laboratory findings (table 2).

The baseline serum 25(OH)D was $74.3 \pm 14.8 \mathrm{nmol} / \mathrm{l}$ in the 15 healthy subjects (table 1 ). NB-UVB course increased serum $25(\mathrm{OH}) \mathrm{D}$ by $17.0 \mathrm{nmol} / \mathrm{l}$ (CI 13.7-20.2, $\mathrm{p}<0.001$ ), or $22.8 \%$ (fig. 1). b CYP27B1 mRNA expression levels in skin biopsies in CKD patients on haemodialysis $(n=10)($ left $)$ and healthy subjects $(n=13)$ (right) before and after a NB-UVB course. Before the NB-UVB course the CYP27B1 levels were significantly $(\mathrm{p}=0.003)$ higher in the CKD patients compared to healthy subjects. The NB-UVB course caused a significant decrease in the CYP27B1 levels in the CKD patients $(\mathrm{p}=0.01)$ and healthy subjects $(\mathrm{p}=0.002)$.

Figure 2 shows that 1 and 2 months after the NB-UVB course, serum $25(\mathrm{OH}) \mathrm{D}$ levels were still significantly higher than at baseline in the CKD patients (mean $69.8 \pm$ 18.1 and $64.5 \pm 22.3 \mathrm{nmol} / \mathrm{l} ; \mathrm{p}<0.001$ and $\mathrm{p}=0.031)$, and in the healthy subjects $(88.3 \pm 19.9$ and $91.8 \pm 19.7 \mathrm{nmol} / \mathrm{l}$; $\mathrm{p}=0.002$ and $\mathrm{p}<0.001)$.

CYP27A1 and CYP27B1 mRNA Expression in the Skin At baseline, the CKD patients showed decreased CYP27A1 mRNA expression $(\mathrm{p}=0.028)$, whereas CYP27B1 mRNA expression was significantly $(\mathrm{p}=0.003)$ increased compared to the healthy subjects (fig. 3a, b). The NB-UVB course caused a significant decrease in the CYP27A1 $(\mathrm{p}=0.018)$ and CYP27B1 $(\mathrm{p}=0.010)$ mRNA expression levels in the CKD patients, and also in the healthy subjects $(\mathrm{p}<0.001, \mathrm{p}=0.002$, respectively; fig. 3a, b). 


\section{Discussion}

In the present study, NB-UVB exposures were given to 14 CKD patients on haemodialysis who were receiving oral cholecalciferol $20 \mu \mathrm{g}$ daily. The supplementation of 20-25 $\mu \mathrm{g}$ of vitamin D daily has been recommended for older people to prevent bone fractures [14], and these amounts are also in common use in Finnish CKD patients on haemodialysis. Despite this supplementation, the mean serum $25(\mathrm{OH}) \mathrm{D}$ concentration was at baseline rather low, i.e. $57.6 \mathrm{nmol} / \mathrm{l}$. In $6(43 \%)$ dialysis patients, the serum $25(\mathrm{OH}) \mathrm{D}$ was $<50.0 \mathrm{nmol} / \mathrm{l}(20.0 \mathrm{ng} / \mathrm{ml})$, which can be considered as vitamin D insufficient [15]. A NB-UVB course given within a 3-week period significantly increased the serum $25(\mathrm{OH}) \mathrm{D}$. The mean concentration was $71.6 \mathrm{nmol} / \mathrm{l}$, and only 1 patient was still vitamin D insufficient. The increase of $25(\mathrm{OH}) \mathrm{D}$ was $24.2 \%$, but this percentage is almost two times lower than in our previous study when the dialysis patients were not on oral vitamin D supplementation [13]. To our knowledge, these studies are the first to show that NB-UVB exposures can be used to improve vitamin $\mathrm{D}$ balance in CKD patients on dialysis. The NB-UVB exposures were easy to give in connection with dialysis sessions, and one exposure took only a few minutes. The NB-UVB treatment cabins are usually available in dermatologic outpatient clinics in the same hospitals as dialysis units. In our university hospital the cost of one NB-UVB exposure is approximately $10 \%$ of one haemodialysis session showing that the cost is not any potential barrier to this treatment. Moreover, the NB-UVB doses were small. So far, this widely used dermatologic treatment has not shown any increased risk for skin cancer $[15,16]$.

In the present study, we followed up serum $25(\mathrm{OH}) \mathrm{D}$ concentrations for 2 months after the NB-UVB course. In contrast to NB-UVB-treated healthy subjects, $25(\mathrm{OH}) \mathrm{D}$ concentrations began to decrease in the CKD patients after 2 months. The more profound decrease of $25(\mathrm{OH}) \mathrm{D}$ may be caused by the higher BMI of the CKD patients compared to healthy subjects and linked to the active metabolism of vitamin D precursors in the fat tissue [7]. Though our present and previous CKD patient series were small, the observed relatively rapid decrease of serum $25(\mathrm{OH}) \mathrm{D}$ suggests that the CKD patients would need a longer NB-UVB course or cyclic NB-UVB exposures to maintain their vitamin D balance. The further limitation of the present study was that the dialysis patients were supplemented by only one dose of cholecalciferol, and a dose $>20 \mu \mathrm{g}$ daily would also be of interest.

Oral Cholecalciferol, UVB and 25(OH)D

in Dialysis Patients
In advanced kidney disease, the kidney is unable to produce $1,25(\mathrm{OH})_{2} \mathrm{D}$ from $25(\mathrm{OH}) \mathrm{D}$ due to loss of renal CYP27B1 activity $[5,6]$. It has been shown in UVB-treated organ cultures of skin that keratinocytes are able to hydroxylate $25(\mathrm{OH}) \mathrm{D}$ to $1,25(\mathrm{OH})_{2} \mathrm{D}$ [17]. The finding that the CYP27B1 enzyme is also outside the kidney is of interest with regard to oral vitamin $\mathrm{D}$ treatment in the CKD patients [18]. In the present study, we found that prior to NB-UVB exposures the CKD patients had significantly increased cutaneous mRNA expression of the CYP27B1 enzyme compared to healthy subjects. The increased cutaneous CYP27B1 levels in the CKD patients supplemented with oral cholecalciferol suggest that the loss of renal activity of this enzyme is at least partially compensated for by the skin. This hypothesis was also supported by the previous study demonstrating that dialysis patients on oral vitamin $\mathrm{D}$ supplementation had enough extrarenal CYP27B1 activity to influence the serum $1,25(\mathrm{OH})_{2} \mathrm{D}$ levels [19]. Interestingly, the NB-UVB course caused a significant decrease in the mRNA expression of CYP27B1 and CYP27A1 in both the CKD patients and healthy subjects. This type of decrease can be expected because there is a very sensitive natural feedback controlling mechanism caused by the UVB-induced increase in cutaneous vitamin D synthesis $[6,7,20]$.

In conclusion, the present study shows that a short NB-UVB course is a rapid and effective way to improve vitamin $\mathrm{D}$ balance also in those dialysis patients who have already had oral vitamin D supplementation. The increased CYP27B1 levels in the patients suggest that the loss of renal activity of this enzyme is at least partly compensated for by the skin.

\section{Acknowledgements}

This study was financially supported by the National Graduate School of Clinical Investigation (M.A.-H.) and by Competitive Research Funding of the Tampere University Hospital (Grant 9M089). We thank nurses Pirjo Honko and Tuija Valjakka for giving the NB-UVB exposures in the study.

References

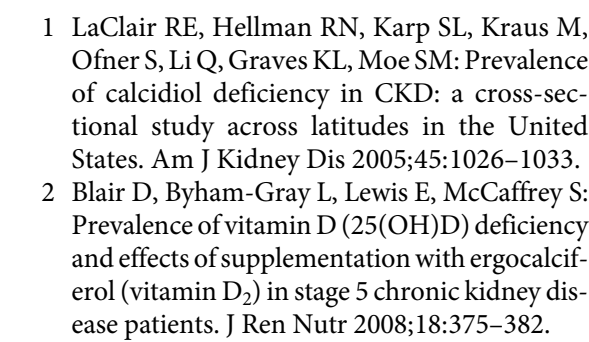

Nephron Clin Pract 2013;124:17-22 DOI: $10.1159 / 000355010$ 
3 Mehrotra R, Kermah D, Budoff M, Salusky IB, Mao SS, Gao YL, Takasu J, Adler S, Norris $\mathrm{K}$ : Hypovitaminosis D in chronic kidney disease. Clin J Am Soc Nephrol 2008;3:11441151.

4 Bhan I, Burnett-Bowie SA, Ye J, Tonelli M, Thadhani R: Clinical measures identify vitamin $\mathrm{D}$ deficiency in dialysis. Clin J Am Soc Nephrol 2010;5:460-467.

5 Pitts TO, Piraino BH, Mitro R, Chen TC, Serge GV, Greenberg A, Puschett JB: Hyperparathyroidism and 1,25-dihydroxyvitamin $\mathrm{D}$ deficiency in mild, moderate, and severe renal failure. J Clin Endocrinol Metab 1988;67: 876-881.

-6 Holick MF: Vitamin D deficiency. N Engl J Med 2007;357:266-281.

7 Lehmann B, Meurer M: Vitamin D metabolism. Dermatol Ther 2010;23:2-12.

$\checkmark 8$ Kidney Disease: Improving Global Outcomes (KDIGO) CKD-MBD Work Group: KDIGO clinical practice guideline for the diagnosis, evaluation, prevention, and treatment of chronic kidney disease-mineral and bone disorder (CKD-MBD). Kidney Int 2009;76:S1S130.

-9 Qunibi WY, Abdellatif A, Sankar S, Hamdan $\mathrm{Z}$, Lin FY, Ingle J, Cadena A, Gelfond J, Kasinath B: Treatment of vitamin D deficiency in CKD patients with ergocalciferol: are current $\mathrm{K} / \mathrm{DOQI}$ treatment guidelines adequate? Clin Nephrol 2010;73:276-285.
10 Kandula P, Dobre M, Schold JD, Schreiber RJ Jr, Mehrotra R, Navaneethan SD: Vitamin D supplementation in chronic kidney disease: a systematic review and meta-analysis of observational studies and randomized controlled trials. Clin J Am Soc Nephrol 2011;6:50-62.

11 Ala-Houhala MJ, Vähävihu K, Hasan T, Kautiainen H, Ylianttila L, Viljakainen HT, Snellman E, Reunala T: Comparison of narrow-band ultraviolet $\mathrm{B}$ exposures and oral vitamin D substitution on serum 25-hydroxyvitamin D concentration. Br J Dermatol 2012; 167:160-164.

12 Bogh MK, Gullstrand J, Svensson A, Ljunggren B, Dorkhan M: Narrow-band ultraviolet $\mathrm{B}$ three times per week is more effective in treating vitamin D deficiency than $1600 \mathrm{IU}$ oral vitamin $\mathrm{D}_{3}$ per day: a randomized clinical trial. Br J Dermatol 2012;167:625-630.

13 Ala-Houhala MJ, Vähävihu K, Hasan T, Kautiainen H, Snellman E, Karisola P, Dombrowski Y, Schauber J, Saha H, Reunala T: Narrow-band ultraviolet $\mathrm{B}$ exposure increases serum vitamin $D$ levels in haemodialysis patients. Nephrol Dial Transplant 2012;27: 2435-2440.

14 Dawson-Hughes B, Heaney RP, Holick MF, Lips P, Meunier PJ, Vieth R: Estimates of optimal vitamin D status. Osteoporos Int 2005; 16:713-716.
15 Patel RV, Clark LN, Lebwohl M, Weinberg JM: Treatments for psoriasis and the risk of malignancy. J Am Acad Dermatol 2009;60: 1001-1017.

16 Hearn RMR, Kerr AC, Rahim KF, Ferguson J, Dawe RS: Incidence of skin cancers in 3,867 patients treated with narrow-band ultraviolet B phototherapy. Br J Dermatol 2008;159:931935.

17 Lehmann B, Knuschke P, Meurer M: The UVBinduced synthesis of vitamin $\mathrm{D}_{3}$ and $1 \alpha, 25$ dihydroxyvitamin $\mathrm{D}_{3}$ (calcitriol)inorganotypic cultures of keratinocytes: effectiveness of the narrow-band Philips TL-01 lamp (311nm). Steroid Biochem Mol Biol 2007;103:682-685.

18 Melamed ML, Thadhani RI: Vitamin D therapy in chronic kidney disease and end-stage renal disease. Clin J Am Soc Nephrol 2012;7:358-365.

19 Jean G, Terrat JC, Vanel T, Hurot JM, Lorriaux C, Mayor B, Chazot C: Evidence for persistent vitamin D 1-alpha-hydroxylation in hemodialysis patients: evolution of serum 1,25-dihydroxycholecalciferol after 6 months of 25-hydroxycholecalciferol treatment. Nephron Clin Pract 2008;110:c58-c65.

20 Schauber J, Dorschner RA, Coda AB, Büchau AS, Liu PT, Kiken D, Helfrich YR, Kang S, Elalieh HZ, Steinmeyer A, Zügel U, Bikle DD, Modlin RL, Gallo RL: Injury enhances TLR2 function and antimicrobial peptide expression through a vitamin D-dependent mechanism. J Clin Invest 2007;117:803-811. 